\title{
ANALISIS NILAI TAMBAH USAHA KERUPUK IKAN CUMI DI DESA WERU, KECAMATAN PACIRAN, KABUPATEN LAMONGAN
}

\author{
Candra Adi Intyas ${ }^{a^{*}}$, Muhamad Firdaus ${ }^{b}$ \\ ${ }^{a}$ Jurusan Sosial Ekonomi Perikanan dan Kelautan, \\ Fakultas Perikanan dan Ilmu Kelautan, Universitas Brawijaya \\ burusan Manajemen Sumberdaya Perairan, \\ Fakultas Perikanan dan Ilmu Kelautan, Universitas Brawijaya \\ *Koresponden penulis : candra.intyas@ub.ac.id
}

\begin{abstract}
Abstrak
Meskipun dikenal sebagai penghasil ikan tangkap terbesar di Jawa Timur, bukan berarti nelayan di Lamongan menunjukkan peningkatan kesejahteraan. Umumnya hasil tangkapan ikan sebagian besar dijual langsung kepada tengkulak (pedagang ikan) dan hanya sedikit saja yang melakukan peningkatan nilai tambah dalam bentuk olahan ikan atau diversifikasi produk, seperti abon ikan, otak-otak ikan, kerupuk ikan dan lain-lain. Tujuan dari penelitian ini adalah untuk menganalisis nilai tambah yang diperoleh dari ikan segar dan cumi setelah diolah menjadi kerupuk ikan cumi oleh rumah tangga nelayan skala kecil yaitu UKM Barokah Sejati. Analisis nilai tambah digunakan untuk mengetahui nilai tambah suatu komoditi karena adanya input fungsional yang dilakukan pada komoditi tersebut. Penentuan lokasi dilakukan secara purposive dengan pertimbangan, bahwa di Desa Weru merupakan desa pesisir yang mayoritas penduduknya berprofesi sebagai nelayan dimana beberapa istri nelayan melakukan kegiatan pengolahan ikan secara tradisional. Jenis penelitian menggunakan metode studi kasus. Analisis data yang digunakan yaitu analisis nilai tambah metode Hayami. Hasil penelitian didapatkan bahwa nilai tambah pengolahan kerupuk ikan cumi Rp -1.697,- / kg dengan rasio nilai tambah sebesar $-3,20 \%$ sedangkan setelah investasi sebesar Rp. 36.925,-/kg dengan rasio nilai tambah 34,87\% (memperhitungkan Nilai Kerja Keluarga) yang artinya setiap Rp. 100 nilai produk kerupuk ikan cumi sebelum investasi diperoleh nilai tambah Rp. -76,82 (merugi) tetapi setelah investasi setiap Rp. 100 diperoleh nilai tambah Rp.34,87
\end{abstract}

Kata kunci : UKM, nilai tambah, kerupuk ikan cumi

\begin{abstract}
Even though known as the biggest fish catch producer in East Java, it does not mean that fishermen in Lamongan show an increase in welfare. Most of the fish catches are sold directly to middlemen (tengkulak) and only few fisherman households did the added value in the form of processed fish or diversification of products, such as fish floss, grilled fish cake, fish crackers and others. The purpose of this study was to analyze the added value obtained from fresh fish and squid that processed into squid crackers by small-scale fishermen households which is UKM Barokah Sejati. Value added analysis is used to find out how much value is added in the commodity because of the adding functional input on the commodity. The location was chosen with purposively consideration that Weru vlllage is a coastal village where the majority of residents' work as fishermen where some fishermen's wives make traditional fish processing activities. The research method uses case studies. The data analysis used is Hayami method. The results showed that the added value of squid crackers from the processing of squid crackers $\mathrm{Rp}-1,697,-/ \mathrm{kg}$ with a value-added ratio of $-3.20 \%$ while after investment of $\mathrm{Rp}$. 36,925 / $\mathrm{kg}$ with a value-added ratio of $34.87 \%$ (the value of family work assumption) which means that before investment every Rp. 100 of fish cracker products has added value Rp. -76.82 (loss) but after investment every Rp. 100 has added value Rp. 34.87.
\end{abstract}

Keywords : Micro business, added value, squid crackers

\section{PENDAHULUAN}

Lamongan merupakan salah satu kabupaten di Provinsi Jawa Timur dengan luas wilayah sekitar $1.812,80 \mathrm{~km}^{2}$ setara 181.280 ha atau $+3.78 \%$ dari luas wilayah Provinsi Jawa Timur dengan panjang garis pantai sepanjang $47 \mathrm{Km}$. Secara geografis, Kabupaten Lamongan terletak pada $6^{\circ} 51^{\prime}-7^{\circ} 23^{\prime}$ Lintang Selatan dan 
$112^{\circ} 33^{\prime}-112^{\circ} 34^{\prime}$ Bujur Timur. Batas wilayah administratif Kabupaten Lamongan adalah :

- Sebelah Utara : Laut Jawa

- Sebelah Timur : Kabupaten Gresik

- Sebelah Selatan : Kab. Jombang dan Kab. Mojokerto

- Sebelah Barat : Kab. Bojonegoro dan Kab. Tuban.

Potensi perikanan yang dimiliki cukup besar, menurut [1] produksi perikanan Lamongan tahun 2017 mencapai 126.565, 46 dengan produksi perikanan tangkap sebesar $74.196,30$ ton dan perikanan budidaya sebesar $52.369,16$ ton. Produksi perikanan tangkap di Lamongan merupakan jumlah terbesar di Jawa Timur.

Meskipun potensi perikanan tangkap di Lamongan sangat besar namun rata - rata nelayan di Lamongan belum bisa dikatakan sejahtera. Hal ini dipengaruhi oleh beberapa faktor, salah satunya adalah dominasi sistem jual beli nelayan yang dikenal dengan sistem "patron - klien" dimana tengkulak menguasai harga beli ikan karena ada ikatan hutang pada nelayan. Oleh karena itu untuk meningkatkan pendapatan rumah tangganya, beberapa rumah tangga melakukan diversifikasi usaha seperti membuat kapal, jaring atau usaha pengolahan ikan secara tradisional seperti membuat kerupuk ikan, terasi ikan, abon ikan, ikan asap, pindang dan lain-lain. Dengan kondisi yang dialami nelayan skala kecil, salah satu usaha yang dilakukan rumah tangga nelayan skala kecil untuk meningkatkan pendapatan adalah mencari alternatif mata pencaharian lain salah satunya dengan mengolah hasil tangkapan ikan secara tradisional sesuai dengan modal yang mereka miliki.

Ikan olahan tradisional, atau "traditional cured" adalah produk yang diolah secara sederhana dan umumnya dilakukan pada skala industri rumah tangga karena alat dan cara pengolahan yang sederhana sehingga tidak membutuhkan modal yang besar. Jenis olahan yang termasuk pada produk olahan tradisional ini adalah ikan pindang, ikan kering atau ikan asin kering, kerupuk ikan, serta produk fermentasi yaitu kecap, peda, terasi, dan sejenisnya. Pengolahan kerupuk ikan di Indonesia merupakan salah satu cara pengolahan tradisional yang cukup berperan dalam memanfaatkan hasil-hasil perikanan dimana rata - rata rumah tangga nelayan skala kecil memilih usaha ini [2].

Pengolahan secara sederhana terhadap hasil tangkapan ikan dapat menciptakan nilai tambah yang diharapkan meningkatkan pendapatan rumah tangga nelayan. Menurut [3] dengan melakukan analisis nilai tambah dapat diketahui besarnya imbalan yang diterima oleh pengusaha dan tenaga kerja. Analisis nilai tambah juga berguna untuk mengetahui berapa tambahan nilai yang terdapat pada satu satuan output yang dihasilkan. Menurut [4] Investasi pribadi memiliki efek yang signifikan secara positif terhadap produksi nilai tambah, penyerapan tenaga kerja dan produktivitas tenaga kerja.

Dalam penelitian ini, peneliti ingin melihat berapa nilai tambah yang didapatkan dengan melakukan usaha pengolahan ikan segar menjadi kerupuk ikan. Produksi kerupuk ikan di kabupaten Lamongan mencapai 11,2 ton pada tahun 2017. Salah satu sentral produksi kerupuk ikan di kabupaten Lamongan terdapat di desa Weru, kecamatan Paciran. Desa Weru merupakan desa pesisir yang mayoritas penduduknya berprofesi sebagai nelayan. Desa Weru memiliki TPI yaitu TPI Weru dengan produksi ikan sebanyak 375, 46 ton. Jumlah penduduknya berjumlah 4.748 jiwa, yang terdiri dari 2.418 pria dan 2.33 wanita [5]. Pada umumnya istri nelayan di desa Weru hanya menjual hasil tangkapan suaminya saja ketika mereka kembali dari melaut tetapi terdapat beberapa istri nelayan yang memiliki insiatif untuk mengolah hasil tangkapan sebagai usaha sampingan salah satunya dengan membuat kerupuk ikan.

Ada beberapa produsen kerupuk ikan di Desa Weru. Namun, hanya sebagian kecil yang masih konsisten memproduksi kerupuk ikan, diantaranya UKM Barokah Sejati. UKM Barokah Sejati memulai usaha kerupuk ikan pada tahun 2012 oleh Ibu Siti Saroh dengan kapasitas produksi per dua hari mencapai $10 \mathrm{~kg}$.

Dari latar belakang tersebut maka tujuan penelitian yaitu menganalisis nilai tambah yang diperoleh rumah tangga nelayan skala kecil dengan mengolah hasil tangkapan menjadi kerupuk ikan

\section{METODE}

Jenis penelitian yang digunakan pada penelitian ini adalah penelitian studi kasus. Menurut [6] Studi kasus adalah penelitian tentang status subjek penelitian yang berkenaan dengan fase spesifik dari keseluruhan personalitas, subjek penelitian dapat berupa individu, kelompok, lembaga maupun masyarakat. Tujuan studi kasus adalah untuk 
memberikan gambaran secara mendetail tentang latar belakang, sifat-sifat serta karakter yang khas dari kasus atau status dari individu kemudian akan dijadikan hal yang bersifat umum.

Penelitian ini mengambil lokasi di Desa Weru karena salah satu lokasi yang memiliki TPI dan pada saat survey didapatkan beberapa rumah tangga nelayan skala kecil mengolah hasil tangkapan ikannya menjadi kerupuk ikan, terasi, kecap ikan, nugget ikan, ikan asin dan lain - lain yang diolah secara tradisional. Pada saat survei ditemukan UKM Barokah Sejati yang dimiliki oleh Bu Siti Saroh yaitu membuat usaha olahan kerupuk ikan cumi. UKM Barokah Sejati dipilih menjadi tempat penelitian karena UKM yang pertama berdiri dan konsisten memproduksi kerupuk ikan cumi dari tahun 2009 hingga sekarang.

Metode analisis data menggunakan analisis nilai tambah metode hayami. Nilai tambah adalah pertambahan nilai yang terjadi karena satu komoditi mengalami proses pengolahan, pengangkutan dan penyimpanan dalam satu proses produksi dengan penggunaan/pemberian input fungsional [7]. Analisis nilai tambah menggunakan metode Hayami bertujuan untuk mengetahui produktivitas, nilai output, nilai tambah, keuntungan, balas jasa terhadap tenaga kerja dan keuntungan pengolahan yang dapat dilihat pada tabel 1 di bawah ini.

Tabel 1. Perhitungan Analisis Nilai Tambah Hasil Olahan

\begin{tabular}{|c|c|}
\hline URAIAN & NILAI \\
\hline \multicolumn{2}{|l|}{ OUTPUT, INPUT, HARGA } \\
\hline 1. Output (kg/prod) & $\mathrm{a}$ \\
\hline 2. Bahan baku (kg/prod) & $\mathrm{b}$ \\
\hline 3. Tenaga kerja (HOK/prod) & $\mathrm{c}$ \\
\hline 4. Faktor konversi $(1 / 2)$ & $\mathrm{d}=\mathrm{a} / \mathrm{b}$ \\
\hline 5. Koefisien tenaga kerja $(3 / 2)$ & $\mathrm{e}=\mathrm{c} / \mathrm{b}$ \\
\hline 6. Harga output $(\mathrm{Rp} / \mathrm{kg})$ & f \\
\hline 7. Upah rata-rata tenaga kerja $(\mathrm{Rp} / \mathrm{HOK})$ & $\mathrm{g}$ \\
\hline \multicolumn{2}{|c|}{ PENDAPATAN DAN KEUNTUNGAN(Rp/kg bahan baku) } \\
\hline 8. Harga input ( $\mathrm{Rp} / \mathrm{kg}$ bahan baku) & $\mathrm{h}$ \\
\hline 9. Sumbangan input lain (Rp/prod) & $\mathrm{i}$ \\
\hline 10. Nilai output $(4 \times 6)$ & $\mathrm{j}=\mathrm{d} \times \mathrm{f}$ \\
\hline 11. a. Nilai tambah $(10-9-8)$ & $\mathrm{k}=\mathrm{j}-\mathrm{h}-\mathrm{i}$ \\
\hline b. Rasio nilai tambah $((11 \mathrm{a} / 10) \times 100 \%)$ & $1 \%=(\mathrm{k} / \mathrm{j}) \times 100 \%$ \\
\hline 12. a Imbalan tenaga kerja $(5 \times 7)$ & $\mathrm{m}=\mathrm{e} \times \mathrm{g}$ \\
\hline b Bagian tenaga kerja $((12 a / 11 a) \times 100 \%)$ & $\mathrm{n} \%=(\mathrm{m} / \mathrm{k}) \times 100 \%$ \\
\hline 13. a Keuntungan $(11 a-12 a)$ & $\mathrm{o}=\mathrm{k}-\mathrm{m}$ \\
\hline b Tingkat Keuntungan $((13 a / 11 a)$ x $100 \%)$ & $\mathrm{p} \%=(\mathrm{o} / \mathrm{k}) \times 100 \%$ \\
\hline \multicolumn{2}{|l|}{ BALAS JASA FAKTOR PRODUKSI } \\
\hline 14 Marjin $(10-8)(\mathrm{Rp} / \mathrm{Kg})$ & $q=j-h$ \\
\hline a. Pendapatan tenaga kerja $((12 \mathrm{a} / 14) \times 100 \%)$ & $\mathrm{r} \%=(\mathrm{m} / \mathrm{q}) \times 100 \%$ \\
\hline b. Sumbangan input lain $((9 / 14) \times 100 \%)$ & $\mathrm{s} \%=(\mathrm{i} / \mathrm{q}) \times 100 \%$ \\
\hline c. Keuntungan perusahaan $((13 \mathrm{a} / 14 \times 100 \%)$ & $\mathrm{t} \%=(\mathrm{o} / \mathrm{q}) \times 100 \%$ \\
\hline
\end{tabular}

Sumber : [6]

\section{HASIL DAN PEMBAHASAN}

Rumah tangga nelayan skala kecil melakukan beberapa alternatif mata pencaharian untuk memenuhi kebutuhan hidupnya karena hasil tangkapan ikan yang semakin tidak menentu dan kondisi musim yang tidak bisa diprediksi.

Pengolahan tradisional menjadi salah satu pilihan bagi rumah tangga nelayan skala kecil karena jumlah hasil tangkapan per nelayan relatif sedikit, jenis dan ukuran ikan yang beragam serta tidak memerlukan modal yang besar salah satunya dengan melakukan pengolahan menjadi kerupuk cumi yang dilakukan oleh UKM Barokah Sejati milik Bu
Siti Saroh. Usaha ini sudah dimulai setelah suaminya meninggal di Tahun 2009. Saat ini $\mathrm{Bu}$ Siti Saroh tinggal bersama anaknya yang menjadi nelayan ikan, terkadang bahan baku didapatkan dari sang anak setelah melaut.

Pengolahan secara sederhana terhadap hasil tangkapan ikan dapat menciptakan nilai tambah (value added) yang diharapkan dapat meningkatkan pendapatan bagi rumah tangga nelayan yaitu usaha pengolahan kerupuk ikan. Menurut [8] kerupuk pada umumnya dibuat dari tepung tapioka sebagai sumber pati dengan penambahan bumbu dan air memiliki kandungan gizi yang rendah. Penambahan gizi kerupuk dapat dilakukan dengan menambahkan daging ikan. Sementara disisi 
lain, jenis ikan sebagai bahan baku utama pada pembuatan kerupuk ikan sangat berpengaruh terhadap warna, tekstur dan rasa kerupuk ikan.

Kerupuk cumi diminati masyarakat karena kandungan protein yang tinggi yaitu $17,9 \mathrm{~g} / 100 \mathrm{~g}$ cumi segar. Proses pembuatan kerupuk cumi secara umum adalah daging cumi yang sudah dibersihkan dan dibuang tintanya diblender serta dicampur dengan tepung tapioka, tepung terigu, garam, gula, serta ekstrak kunyit sesuai perlakuan [9]. Terdapat tahapan untuk proses produksi kerupuk cumi dengan penjelasan sebagai berikut:

1. Persiapan bahan baku.

Bahan baku utama untuk pembuatan kerupuk ikan cumi adalah ikan kecil yang sering disebut ikan balak/tonang dan cumi - cumi.

2. Ikan yang telah dibersihkan dari tulangnya isi perut dan kulitnya serta cumi yang diambil tintanya dicuci dan dihaluskan dengan menambahkan sedikit air menggunakan blender.

3. Bahan baku yang telah dihaluskan dicampurkan dengan bahan tambahan yang telah dihaluskan yaitu bawang putih, garam dan penyedap rasa. Diaduk agar merata kemudian dimasukkan ke mesin penggiling dengan ditambahkan tepung tapioka agar menjadi adonan kerupuk.

4. Adonan yang masih kasar dari mesin penggiling diulen kembali hingga menjadi kalis. Proses pengkalisan ini merupakan titik kritis dalam pembuatan kerupuk, karena adonan yang kurang kalis akan menyebabkan hasil daya kembang kerupuk kurang baik.

5. Setelah adonan kalis, adonan dicetak dengan bentuk lonjong seperti lontong sesuai ukuran agar memperoleh bentuk kerupuk yang pipih pada saat dipotong yang dikemas dalam plastic satu kiloan untuk kemudian direbus kurang lebih 90 menit dengan api besar.

6. Setelah adonan direbus didinginkan di freezer selama kurang lebih 24 jam agar adonan memadat.

7. Setelah pendinginan adonan telah padat dan mengeras dilakukan pemotongan adonan untuk menjadi kerupuk.
8. Kemudian kerupuk dijemur diatas para para selama dua hari di bawah sinar matahari mulai pukul 08.00 - 17.00 wib. Tujuan dari penjemuran ini adalah untuk mengurangi kadar air dalam kerupuk yang akan mempengaruhi daya kembang kerupuk ketika digoreng. Apabila Pengeringan kerupuk kurang maka ketika digoreng menjadi tidak mengembang sempurna.

Proses produksi kerupuk cumi dapat dilihat pada gambar 1 di bawah ini.

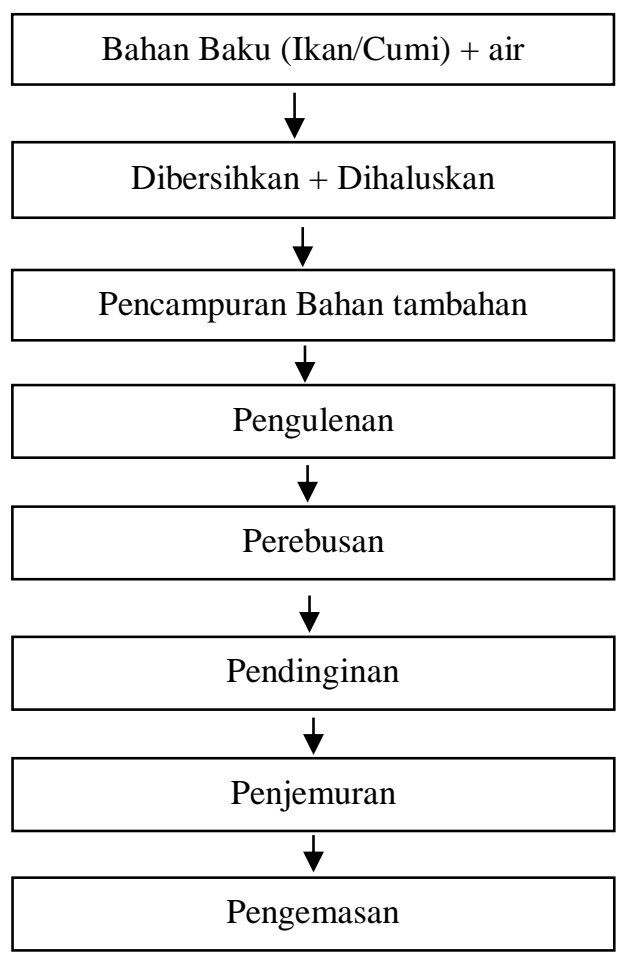

Gambar 1. Alur Produksi Kerupuk Ikan Cumi

Pada pembuatan kerupuk ikan cumi, terdapat sumbangan input lain merupakan bahan yang dapat menunjang proses produksi atau pembuatan suatu produk yang meliputi biaya penyusutan peralatan, biaya perawatan alat, biaya sewa tanah, biaya listrik dan biaya bahan penolong. Besarnya komponen sumbangan input lain yang digunakan untuk analisis nilai tambah yang dapat dilihat pada tabel 2 dibawah ini 
Tabel 2. Komponen Sumbangan Input Lain Pada Perhitungan Nilai Tambah pada Usaha Kerupuk Ikan Cumi pada UKM Barokah Sejati di Desa Weru, Kecamatan Paciran Selama 1 kali produksi

\begin{tabular}{|c|c|c|c|c|}
\hline No & Uraian & Satuan & 1 & 2 \\
\hline 1 & Biaya penyusutan peralatan & $\mathrm{Rp}$ & 2.946 & 9.141 \\
\hline 2 & Biaya perawatan alat & $\mathrm{Rp}$ & 6.250 & 25.000 \\
\hline 3 & Biaya Sewa Tanah & $\mathrm{Rp}$ & 12.500 & 12.500 \\
\hline 4 & Biaya Listrik & $\mathrm{Rp}$ & 5.000 & 6.250 \\
\hline 5 & Biaya Tenaga Kerja (NKK) & $\mathrm{Rp}$ & 50.000 & 50.000 \\
\hline \multirow[t]{6}{*}{6} & Biaya bahan penolong & & & \\
\hline & - Bahan bakar & $\mathrm{Rp}$ & 7.000 & 18.000 \\
\hline & - Bahan Tambahan & $\mathrm{Rp}$ & 231.100 & 231.100 \\
\hline & - Bahan Pengemas & $\mathrm{Rp}$ & 1.725 & 86.250 \\
\hline & Total Sumbangan input lain & $\mathrm{Rp}$ & 316.521 & 438.241 \\
\hline & Nilai sumbangan input lain per kg bahan baku utama & $\mathrm{Rp} / \mathrm{kg}$ & 37.238 & $\mathbf{5 1 . 5 5 8}$ \\
\hline
\end{tabular}

Keterangan : 1. Sebelum Investasi

$$
\text { 2. Setelah Investasi }
$$

Komponen sumbangan input lain pada Tabel 2 mengeluarkan beberapa komponen biaya, antara lain: biaya penyusutan peralatan berasal dari peralatan sebelum investasi sebesar Rp. 2.946,-/produksi yaitu dandang, baskom, blender sedikit rusak, centong nasi, timbangan, pisau, talenan, alat pemotong kerupuk, talam, para-para, kulkas, staples dan cobek besar yang kemudian setelah investasi sebesar Rp. 9.141,-karena ada penambahan mesin pengaduk adonan mekanis, dandang, blender, sealer, kompor dan tabung elpiji. Menurut [10] biaya penyusutan modal tetap harus dialokasikan sepanjang umur ekonomis, jika biaya penyusutan dialokasikan tanpa dasar yang benar maka hal itu dapat berpengaruh terhadap perhitungan beban pokok produksi karena biaya penyusutan terutama mesin dan peralatan serta bangunan pabrik merupakan salah satu unsur yang signifikan dan bernilai material dari beban overhead pabrik.

Biaya sewa tanah per produksi sebesar Rp. 12.500,- dalam satu kali produksi. Biaya listrik sebelum investasi sebesar Rp. 5.000,- I produksi tetapi setelah investasi naik sebesar Rp. 6.250,-/produksi karena adanya penambahan mesin pengaduk mekanis dan mesin sealer yang menambah penggunaan biaya listrik.

Tenaga kerja adalah jumlah hari orang kerja yang terlibat langsung dalam satu kali proses produksi pembuatan kerupuk ikan dengan tenaga kerja yang terlibat dalam proses produksi kerupuk ikan [11]. Biaya tenaga kerja menggunakan Nilai Kerja Keluarga (NKK) dengan asumsi tenaga kerja per HOK adalah Rp. 50.000,- Biaya bahan penolong terdiri dari biaya bahan bakar, bahan tambahan dan bahan pengemas yaitu:

a. Bahan bakar yang digunakan sebelum investasi adalah kayu bakar dengan kompor bata yang dapat didapatkan dengan mudah dengan harga Rp. 7000,/produksi namun setelah investasi menggunakan gas elpiji dengan kompor gas dengan biaya Rp. 18.000,-/produksi.

b. Bahan tambahan yaitu bumbu berupa tepung tapioka, bawang putih, masako, gula, garam, air dan penyedap rasa dengan biaya sebesar Rp. 231.100,-/ per produksi.

c. Bahan pengemas sebelum investasi adalah plastik kemasan $1 \mathrm{~kg}$-an dan staples dengan biaya sebesar Rp. 1.725,-/produksi sedangkan setelah investasi menggunakan plastik khusus kemasan 250gr dengan label kemasannya membutuhkan biaya Rp. 86.250,-/produksi

Dari hasil penelitian didapatkan nilai tambah usaha pengolahan kerupuk ikan cumi pada tabel 3 dibawah ini. 
Tabel 3. Analisis Nilai Tambah Usaha Kerupuk Ikan Cumi UKM Barokah Sejati di Desa Weru, Kecamatan Paciran Selama 1 kali produksi

\begin{tabular}{|c|c|c|}
\hline URAIAN & 1 & 2 \\
\hline \multicolumn{3}{|l|}{ OUTPUT, INPUT, HARGA } \\
\hline 1. Output (kg/prod) & 15 & 15 \\
\hline 2. Bahan baku (kg/prod) & 8,5 & 8,5 \\
\hline 3. Tenaga kerja (HOK/prod) & 6,6 & 5,7 \\
\hline 4. Faktor konversi $(1 / 2)$ & 1,76 & 1,76 \\
\hline 5. Koefisien tenaga kerja $(3 / 2)$ & 0,78 & 0,67 \\
\hline 6. Harga output $(\mathrm{Rp} / \mathrm{kg})$ & 30.000 & 60.000 \\
\hline 7. Upah rata-rata tenaga kerja (Rp/HOK) & 50.000 & 50.000 \\
\hline \multicolumn{3}{|l|}{ PENDAPATAN DAN KEUNTUNGAN } \\
\hline 8. Harga input ( $\mathrm{Rp} / \mathrm{kg}$ bahan baku) & 17.400 & 17.400 \\
\hline 9. Sumbangan input lain ( $\mathrm{Rp} / \mathrm{kg}$ bahan baku) & 37.238 & 51.558 \\
\hline 10. Nilai output $(4 \times 6)$ & 52.941 & 105.882 \\
\hline 11.a. Nilai tambah $(10-9-8)$ & -1.697 & 36.925 \\
\hline b. Rasio nilai tambah $((11 \mathrm{a} / 10) \times 100 \%)$ & $-3,20$ & 34,87 \\
\hline 12.a Imbalan tenaga kerja $(5 \times 7)$ & 38.971 & 33.456 \\
\hline b Bagian tenaga kerja $((12 \mathrm{a} / 11 \mathrm{a}) \times 100 \%)$ & $-2.297,02$ & 90,61 \\
\hline 13.a Keuntungan $(11 a-12 a)$ & -40.667 & 3.469 \\
\hline b. Tingkat Keuntungan $((13 \mathrm{a} / 10)$ x $100 \%)$ & $-76,82$ & 3,28 \\
\hline \multicolumn{3}{|l|}{ BALAS JASA FAKTOR PRODUKSI } \\
\hline 14 Marjin $(10-8)(\mathrm{Rp} / \mathrm{kg})$ & 35.541 & 88.482 \\
\hline a. Pendapatan tenaga kerja $((12 \mathrm{a} / 14) \times 100 \%)$ & 1,10 & 0,38 \\
\hline b. Sumbangan input lain $((9 / 14) \times 100 \%)$ & 104,77 & 58,27 \\
\hline c. Keuntungan perusahaan $((13 \mathrm{a} / 14 \mathrm{x} 100 \%)$ & $-114,42$ & 3,92 \\
\hline
\end{tabular}

$$
\text { 2. Setelah Investasi }
$$

Dari hasil perhitungan rata -rata nilai tambah pada Tabel 3, terdapat dua perhitungan dimana perhitungan yang kedua terdapat investasi yang dilakukan berupa penambahan peralatan serta pelatihan peningkatan inovasi berupa perbaikan kemasan, ijin PIRT, masa kadaluwarsa dan pemasaran Online.

\section{Output, Input dan Harga}

Hasil produksi/ output selama satu kali proses produksi pada usaha olahan kerupuk ikan cumi sebesar $15 \mathrm{~kg} /$ produksi dengan penggunaan bahan baku sebesar 8,5 $\mathrm{kg} /$ produksi. Tenaga kerja dalam proses pengolahan kerupuk ikan cumi dalam satu kali proses produksi sebelum investasi sebesar 6,6 HOK/produksi sedangkan setelah investasi sebesar 5,7 HOK/produksi. Jumlah $\mathrm{HOK} /$ produksi sebelum investasi lebih besar dibandingkan dengan setelah investasi dikarenakan proses pengadukan bahan baku yang ditambahkan dengan tepung kanji (pengulenan) dilakukan secara manual menggunakan tangan dan proses perebusan menggunakan kayu bakar dan kompor bata serta penjemuran yang sepenuhnya menggunakan sinar matahari sehingga setelah investasi lama waktu proses produksi berkurang setelah penggunaan alat pada kegiatan pencampuran bahan, pengulenan dan proses perebusan.

Harga output kerupuk ikan cumi yang diperoleh sebelum investasi sebesar Rp 30.000, -/kg. Harga output dipatok oleh pemilik UKM Barokah Sejati dengan menggunakan perhitungan kasar (feeling) sedangkan setelah investasi harga output sebesar Rp. 60.000,-/kg yang dihitung berdasarkan strategi harga berdasarkan biaya. Besarnya faktor konversi pada satu kali proses produksi adalah 1,76 yang berarti $1 \mathrm{~kg}$ bahan baku menghasilkan $1,76 \mathrm{~kg}$ kerupuk ikan. Koefisien tenaga kerja adalah nilai pembagian dari jumlah jam kerja tenaga kerja yang digunakan dengan jumlah bahan baku yang digunakan dalam kegiatan produksi. Koefisien tenaga kerja menunjukkan banyaknya jam kerja tenaga kerja yang diperlukan untuk mengolah satu satuan input [12]. Koefisien tenaga kerja untuk mengolah bahan baku menjadi kerupuk ikan cumi sebelum investasi adalah 0,78 HOK atau 6,24 jam kerja yang berarti $1 \mathrm{~kg}$ bahan baku/input dibutuhkan tenaga kerja sebanyak $0,78 \mathrm{HOK}$ atau 6,24 jam kerja sedangkan setelah investasi menjadi adalah 0,67 HOK atau 5,35 jam kerja yang berarti $1 \mathrm{~kg}$ bahan baku/input dibutuhkan tenaga kerja sebanyak 0,67 HOK atau 5,35 jam 
kerja. Lama jam kerja ini termasuk dalam proses pendinginan dan penjemuran kerupuk. Nilai koefisien tenaga kerja pada setelah investasi lebih sedikit dikarenakan adanya penggunaan alat mekanis yang mempercepat proses pengulenan dan perebusan. Pada pembuatan kerupuk ikan cumi sebelum investasi membutuhkan waktu sebanyak 53 jam dan setelah investasi sebanyak 45,5 jam dengan bahan baku yang digunakan $8,5 \mathrm{~kg}$ ikan segar, jadi koefisien tenaga kerja yang diperoleh berturut - turut sebesar Rp 0,78 dan Rp. 0,76.

\section{Pendapatan Dan Keuntungan}

Harga input (bahan baku) yang digunakan adalah sumber daya ikan hasil melaut yang langsung diolah rata - rata seharga sebesar $\mathrm{Rp}$. $5.000,-/ \mathrm{kg}$ untuk harga ikan tonang/balak sedangkan cumi seharga Rp. 40.000/kg.

Besarnya sumbangan input lain yang dikeluarkan sebelum investasi sebesar $\mathrm{Rp}$. 37.328 , - $\mathrm{kg} /$ produksi dan setelah investasi sebesar Rp. 51.558,- kg/produksi. Komponen sumbangan input lain bisa dilihat pada tabel 2 .

Nilai tambah merupakan sebuah nilai yang ditambahkan pada suatu komoditas karena komoditas tersebut akan mengalami beberapa proses produksi. Nilai tambah dapat diartikan sebagai selisih antara nilai bahan baku dengan nilai produk [13]. Nilai tambah dari proses pengolahan ikan segar menjadi kerupuk ikan sebelum investasi sebesar $\mathrm{Rp}-1.697,-\quad / \mathrm{kg}$ dengan rasio nilai tambah sebesar $-3,20 \%$ sedangkan setelah investasi sebesar Rp. $36.925,-/ \mathrm{kg}$ dengan rasio nilai tambah $34,87 \%$.

Tenaga kerja pada pembuatan kerupuk ikan cumi menggunakan tenaga sendiri dari pemilik sehingga memperhitungkan Nilai Kerja Keluarga (NKK) sehingga imbalan tenaga kerja yang diberikan dari setiap kilogram bahan baku yang diolah menjadi kerupuk ikan cumi sebelum investasi sebesar Rp. 38.971,sedangkan setelah investasi sebesar Rp. 33.456,-

Keuntungan adalah selisih antara hasil penjualan dan biaya yang dikeluarkan [14]. Besarnya keuntungan yang diperoleh dari proses pengolahan kerupuk ikan cumi sebelum investasi adalah $\mathrm{Rp}-40.667,-/ \mathrm{kg}$ dengan tingkat keuntungan sebesar $-76,82 \%$ dari nilai produk/output sedangkan setelah investasi besarnya keuntungan adalah Rp. $3.469,-/ \mathrm{kg}$ dengan tingkat keuntungan sebesar 3,28\%.

\section{Balas Jasa Faktor Produksi}

Sebelum investasi tiap pengolahan $1 \mathrm{~kg}$ bahan baku menjadi kerupuk ikan cumi diperoleh margin sebesar Rp 35.541,- yang didistribusikan untuk masing-masing faktor yaitu pendapatan tenaga kerja $1,10 \%$, sumbangan input lain 104,77 dan keuntungan usaha $-114,42 \%$ sedangkan setelah investasi diperoleh margin sebesar Rp. 88.482,- dengan pendapatan tenaga kerja sebesar 0,38\%, sumbangan input lain 58,27\% dan keuntungan usaha 3,92\%. Menurut [13] nilai tambah dan keuntungan yang diperoleh industri pengolahan ikan sangat dipengaruhi oleh biaya produksi yang digunakan, agar dapat meningkatkan nilai tambah dan keuntungan maka perlu mengefisienkan biaya produksi.

\section{KESIMPULAN DAN SARAN}

Dari hasil penelitian, didapatkan nilai tambah usaha pengolahan kerupuk ikan cumi sebelum investasi sebesar Rp -1.697,- $/ \mathrm{kg}$ dengan rasio nilai tambah sebesar $-3,20 \%$ sedangkan setelah investasi sebesar Rp. $36.925,-/ \mathrm{kg}$ dengan rasio nilai tambah $34,87 \%$ (asumsi memperhitungkan NKK). Sebelum investasi nilai tambah masih minus karena tidak mempertimbangkan NKK dan penentuan harga yang berdasarkan feeling saja dari pemilik sehingga UKM Barokah Sejati merugi.

Dengan pemberian investasi pada UKM Barokah Sejati, nilai tambah menjadi positif namun masih diperlukan pelatihan lebih mendalam terkait dengan penggunaan media promosi online serta perlunya penambahan investasi berupa alat pengering mekanis agar dapat mempercepat proses pengeringan yang masih menggunakan sinar matahari sehingga membutuhkan waktu lama.

\section{DAFTAR PUSTAKA}

[1] BPS-Provinsi Jawa Timur, "Provinsi Jawa Timur dalam Angka 2018," Jawa Timur, 2018.

[2] Irianto, H.E., dan Giyatmi, S. 2009. Teknologi Pengolahan Hasil Perikanan. Penerbit Universitas Terbuka. Jakarta.

[3] Purba, Manajemen Manunggal Bagi Wiraswasta. Jakarta: Pustaka Dian, 1986.

[4] Jamaliah, "The Effect of Investment to 
Value Added Production, Employment Absorption, Productivity, and Employees' Economic Welfare in Manufacturing Industry Sector in West Kalimantan Province," Procedia - Soc. Behav. Sci., vol. 219, pp. 387-393, 2016, doi: $10.1016 /$ j.sbspro.2016.05.060.

[5] B. P. S. Kecamatan Lamongan, "Kecamatan Lamongan Dalam Angka 2018,” Kecamatan Lamongan, 2018.

[6] M. Nazir, Metode Penelitian. Jakarta: PT Ghalia Indonesia, 2003.

[7] Ramli; Budi Setiawan; Imam Santoso; Siti Asmaul Mustaniroh, "Analisis Kelayakan Usaha Dan Nilai Tambah Kerupuk Cumi," Jurnal Keuangan dan Bisnis, vol. 17, no. 1, pp. 32-50, 2019.

[8] J. Jumiati, D. Ratnasari, and A. Sudianto, "Pengaruh Penggunaan Ekstrak Kunyit (Curcuma domestica) Terhadap Mutu Kerupuk Cumi (Loligo sp.), J. Ilmu Perikan. dan Kelautan, vol. 11, no. 1, p. 55, 2019, doi: 10.20473/jipk.v11i1.11914.

[9] J. S. Setiawan, "Kajian Terhadap Beberapa Metode Penyusutan Dan Pengaruhnya Terhadap Perhitungan Beban Pokok Penjualan (Cost Of Good Sold)," J. Akunt. Keuang., vol. 3, no. 2, pp. 157-173, 2001.

[10] M. Berlia, I. Gumilar, L. P. S. Yuliadi, and A. Nurhayati, "Analisis Usaha Dan Nilai Tambah Produk Kerupuk Berbahan Baku Ikan Dan Udang ( Studi Kasus Di Perusahaan Sri Tanjung Kabupaten Indramayu )," Perikan. dan Kelaut., vol. 8, no. 2, pp. 118-125, 2017.

[11] M. Hayami, Yujiro; Kawagoe, Toshihiko; Morooka, Yoshinori; Siregar, Agricultural Marketing and Processing in Upland Java A Perspective From A Sunda Village. CGPRT Center, 1987.

[12] M. Rosita, K. Hidayat, and I. Maflahah, "Analisis Nilai Tambah Olahan Ikan Peperek ( Leiognathus Equulus ) Menjadi Ikan Peperek Crispy Menggunakan Metode Value Engineering Value Added Analysis Of Peperek Fish ( Leiognathus
Equulus ) Being Peperek Crispy Fish Using Value Engineering Method," $J$. Ilm. Perikan. dan Kelaut., vol. 10, no. 1, pp. 21-34, 2018.

[13] E. Ruauw, "Analisis Keuntungan Dan Nilai Tambah Agriindustri Manisan Pala Ud Putri Di Kota Bitung," AgriSosioekonomi, vol. 8, no. 1, p. 31, 2015, doi: 10.35791/agrsosek.8.1.2012.7359.

[14] V. P. Aji, R. Yudhistira, and W. Sutopo, "Analisis Nilai Tambah Pengolahan Ikan Lemuru Menggunakan Metode Hayami," J. Ilm. Tek. Ind., vol. 17, no. 1, p. 56, 2018, doi: 10.23917/jiti.v17i1.5611. 